Article

\title{
Experimental Analysis of Thermal Runaway in 18650 Cylindrical Li-Ion Cells Using an Accelerating Rate Calorimeter
}

\author{
Boxia Lei, Wenjiao Zhao *, Carlos Ziebert, Nils Uhlmann, Magnus Rohde and Hans Jürgen Seifert
}

Institute of Applied Materials-Applied Materials Physics, Karlsruhe Institute of Technology, 76344 Eggenstein-Leopoldshafen, Germany; boxia.lei@kit.edu (B.L.); carlos.ziebert@kit.edu (C.Z.); nils.uhlmann@kit.edu (N.U.); magnus.rohde@kit.edu (M.R.); hans.seifert@kit.edu (H.J.S.)

* Correspondence: wenjiao.zhao@kit.edu; Tel.: +49-721-6082-8555

Academic Editor: Andreas Jossen

Received: 10 February 2017; Accepted: 5 April 2017; Published: 12 April 2017

\begin{abstract}
In this work, commercial 18650 lithium-ion cells with $\mathrm{LiMn}_{2} \mathrm{O}_{4}, \mathrm{LiFePO}_{4}$, and $\mathrm{Li}\left(\mathrm{Ni}_{0.33} \mathrm{Mn}_{0.33} \mathrm{Co}_{0.33}\right) \mathrm{O}_{2}$ cathodes were exposed to external heating in an accelerating rate calorimeter (es-ARC, Thermal Hazard Technology (THT), Bletchley, UK), to investigate the thermal behavior under abuse conditions. New procedures for measuring the external and internal pressure change of cells were developed. The external pressure was measured utilizing a gas-tight cylinder inside the calorimeter chamber, in order to detect the venting of the cells. For internal pressure measurements, a pressure line connected to a pressure transducer was directly inserted into the cell. During the thermal runaway experiments, three stages (low rate, medium rate, and high rate reactions) were observed. Both the pressure and temperature change indicated different stages of exothermic reactions, which produced gases or/and heat. The onset temperature of the thermal runaway was estimated according to the temperature and pressure changes. Moreover, the different activation energies for the exothermic reactions could be derived from Arrhenius plots.
\end{abstract}

Keywords: Li-ion cell; thermal runaway; accelerating rate calorimeter (ARC); pressure change

\section{Introduction}

To eradicate the dependence on petroleum and to reduce $\mathrm{CO}_{2}$ emissions, the best near-term solutions for vehicles are electric (EV) and hybrid electric vehicles (HEVs). However, in order for them to extensively penetrate the market, one of the most urgent requirements is to develop lithium-ion cells and batteries, which are safe and reliable, even at higher temperatures. Several exothermic chemical reactions can occur inside a cell while the temperature rises. This may generate heat that accumulates inside the cell and accelerates the chemical reaction between the cell components, if the heat transfer to the surroundings is not sufficient. In this case, thermal runaway can occur, resulting in leaks, smoke, gas venting, flames, etc., which may lead to a fire or explosion.

To describe the thermal runaway, the main exothermic chemical reactions have to be identified. According to [1-3], the thermal runaway process can be described by four main steps:

(1) At T $>T_{1}$, the solid-electrolyte interface (SEI) decomposes in an exothermic reaction;

(2) At T $>\mathrm{T}_{2}$, an exothermic reaction between the intercalated Li-ions and the electrolyte starts;

(3) At $\mathrm{T}>\mathrm{T}_{3}$, an exothermic reaction between the positive material and the electrolyte takes place with the evolution of oxygen inside the cell;

(4) At T $>T_{4}$, the electrolyte decomposes. 
A literature overview is given in Table 1. Abraham et al. [3] presented ARC measurements on 18650 lithium-ion cells to decipher the sequence of events leading to thermal runaway. At $84{ }^{\circ} \mathrm{C}$, self-heating of the cell started. The gases generated in the cell were analyzed by gas chromatography/ mass spectroscopy (GC/MS). Jhu et al. [4,5], Chen et al. [6], and Lu et al. [7] studied thermal runaway characteristics (initial exothermic temperature, self-heating rate, pressure rise rate, maximum temperature, and pressure) of Li-ion cells with different state of charge (SOC) with vent sizing package 2 (VSP2). The cathode materials of their tested commercial batteries were $\mathrm{LiCoO}_{2}$, $\mathrm{Li}\left(\mathrm{Ni}_{1 / 3} \mathrm{Co}_{1 / 3} \mathrm{Mn}_{1 / 3}\right) \mathrm{O}_{2}$, and $\mathrm{LiFePO}_{4}$. For all cathode materials, high SOC levels aggravated the exothermic reactions. They also compared the self-heating behaviors of cells with different voltages by the heat of reaction $(\Delta H)$, which was the product of mass of a cell, the specific heat capacity of the cell, and the rise of temperature under adiabatic conditions [4-6,8]. In addition, the activation energy and the frequency factor were calculated with the Arrhenius equation. Fleischhammer et al. [8] showed the differences in the safety behavior between un-aged and aged $18650 \mathrm{Li}$-ion cells by ARC. The cells that were cycled at a low temperature were proven to be the most hazardous, in comparison to the un-aged cells and cells cycled at a high current. Hence, lithium plating leads to a significant increase of heat formation and the ageing history has a strong influence on the safety of the cells. Mendoza-Hernandez et al. [9] used accelerating rate calorimeter (ARC) to study the thermal runaway behavior of $\mathrm{LiCoO}_{2}$ (LCO) and $\mathrm{LiMn}_{2} \mathrm{O}_{4}$ cathode materials at different SOCs. The cell with the $\mathrm{LiMn}_{2} \mathrm{O}_{4}$ cathode material was found to be more thermally stable than the cell with $\mathrm{LiCoO}_{2}$. In a recent report of the Sandia National Laboratories [10], the effects of cell size on the thermal runaway energetics of the cylindrical cells from 3 to $50 \mathrm{Ah}$ of both $\mathrm{LiFePO}_{4}$ (LFP) and $\mathrm{LiNi}_{0.80} \mathrm{Co}_{0.15} \mathrm{Al}_{0.05} \mathrm{O}_{2}$ (NCA) chemistries were studied. The results showed that for both LFP and NCA cells, the normalized heating rate $(\mathrm{W} / \mathrm{Ah})$ increases roughly linearly for cells from 3 to $38 \mathrm{Ah}$, while the normalized total heat released $(\mathrm{kJ} / \mathrm{Ah})$ is relatively constant over that cell size range. Selman et al. [11] also used ARC to study the thermal runaway behavior of $\mathrm{LiCoO}_{2}$ cathode materials at different voltages. The fully charged Li-ion cell had the lowest onset self-heating temperature.

Golubkov et al. [12] ran thermal runaway tests on batteries of $\mathrm{LiFePO}_{4}$ (LFP), $\mathrm{Li}\left(\mathrm{Ni}_{0.45} \mathrm{Mn}_{0.45} \mathrm{Co}_{0.10}\right) \mathrm{O}_{2}$ (NMC), and blended $\mathrm{LCO} / \mathrm{NMC}$ cathode materials by using a pressure-tight and airtight reactor, which was able to collect gases. $\mathrm{CO}, \mathrm{CO}_{2}$, and $\mathrm{H}_{2}$ represented about $80 \%$ of the produced gases, and the others were $\mathrm{CH}_{4}$ and $\mathrm{C}_{2} \mathrm{H}_{4}$. The onset temperatures and amount of released gas of LFP, NMC, and LCO/NMC were $195{ }^{\circ} \mathrm{C}$ and $50 \mathrm{mmol}, 170{ }^{\circ} \mathrm{C}$ and $150 \mathrm{mmol}, 150{ }^{\circ} \mathrm{C}$ and $270 \mathrm{mmol}$, respectively.

In this work, four kinds of experimental methods were applied to measure the surface temperature of new unaged commercial 18650 cells, the external pressure change due to the released gases, and the internal pressure change in re-sealed cells. For the internal pressure test, a hole was drilled via the tab welding and the housing of the cell, a pressure line was then introduced, and finally, the cell was resealed using epoxy resin. Before each test, the cells were charged to SOC 100. Because this study was focused on the elaboration of the correlation between temperature and pressure using different testing methods, only unaged cells and SOC 100 were considered. The correlation between the pressure and temperature behavior of lithium ion cells can characterize the degree of violence of thermal runaway [4], and is very helpful in defining the threshold, the stages of thermal runaway, and the different reactions which occur during thermal runaway. 
Table 1. Literature overview on accelerating rate calorimetry measurements of thermal runaway behavior by cylindrical lithium-ion cells. SOC: state of charge; NCA: lithium nickel cobalt aluminum oxide; LCO: lithium cobalt oxide; NMC: lithium nickel manganese cobalt oxide; LFP: LiFePO4; LMO: LiMn $2 \mathrm{O}_{4}$; ARC: accelerating rate calorimeter; VSP: vent sizing package; and BTPV: battery testing pressure vessel.

\begin{tabular}{|c|c|c|c|c|c|c|c|c|c|c|c|c|}
\hline \multirow[b]{2}{*}{ Author } & \multicolumn{5}{|c|}{ Cell Type } & \multirow{2}{*}{$\begin{array}{l}\text { Calorimeter } \\
\text { Type }\end{array}$} & \multirow{2}{*}{$\begin{array}{l}\text { SOC in } \% \text { or } \\
\text { Voltage in V }\end{array}$} & \multirow{2}{*}{$\begin{array}{c}\text { Onset } \\
\text { Temperature of } \\
\text { Self-Heating in }{ }^{\circ} \mathrm{C}\end{array}$} & \multirow{2}{*}{$\begin{array}{c}\text { Maximum } \\
\text { Temperature } \\
T_{\max } \text { in }{ }^{\circ} \mathrm{C}\end{array}$} & \multirow{2}{*}{$\begin{array}{l}\text { Heat of } \\
\text { Reaction } \\
\Delta \mathrm{H} \text { in } \mathrm{kJ}\end{array}$} & \multirow{2}{*}{$T_{\text {Vent }}$ in } & \multirow{2}{*}{$\begin{array}{c}\text { Maximum } \\
\text { pressure } \\
P_{\max } \text { in Bar }\end{array}$} \\
\hline & Manufacturer/Name & $\begin{array}{l}\text { Capacity } \\
\text { in Ah }\end{array}$ & Dimensions & Weight in $\mathrm{g}$ & $\begin{array}{c}\text { Materials } \\
\text { (Cathode/Anode) }\end{array}$ & & & & & & & \\
\hline $\begin{array}{c}\text { Abraham } \\
{[3]}\end{array}$ & Quallion LLC, Sylmar, CA, USA/- & 1 & $\begin{array}{l}\text { Cylindrical } \\
18650\end{array}$ & - & NCA/graphite & ARC & 100 & 84 & - & - & 124 & - \\
\hline \multirow{2}{*}{ Jhu [4] } & - & 2.6 & $\begin{array}{l}\text { Cylindrical } \\
18650\end{array}$ & 44.9 & $\mathrm{LCO} /-$ & \multirow[t]{2}{*}{ VSP2 } & 100 & 131.5 & 708.8 & 18.9 & - & 18.6 \\
\hline & - & 2 & $\begin{array}{l}\text { Cylindrical } \\
18650\end{array}$ & 41.7 & $\mathrm{NMC} /-$ & & 100 & 175.4 & 665.6 & 14.9 & - & 11.3 \\
\hline \multirow{4}{*}{ Jhu [5] } & $\begin{array}{c}\text { Sanyo Electric Co. Ltd., Osaka, } \\
\text { Japan/UR18650F }\end{array}$ & \multirow{4}{*}{2.6} & \multirow{4}{*}{$\begin{array}{l}\text { Cylindrical } \\
18650\end{array}$} & 45.5 & \multirow{4}{*}{$\mathrm{LCO} /-$} & \multirow{4}{*}{ VSP2 } & $\begin{array}{l}4.2 \\
3.7 \\
\end{array}$ & $\begin{array}{l}131.3 \\
172.8 \\
\end{array}$ & $\begin{array}{l}708.7 \\
402.6\end{array}$ & $\begin{array}{l}19.2 \\
7.7 \\
\end{array}$ & - & $\begin{array}{l}13.5 \\
3.6 \\
\end{array}$ \\
\hline & $\begin{array}{l}\text { Sony Energy Devices Corporation, } \\
\text { Fukushima, Japan/SE US18650GR }\end{array}$ & & & 44.5 & & & $\begin{array}{l}4.2 \\
3.7\end{array}$ & $\begin{array}{l}125.2 \\
154.8\end{array}$ & $\begin{array}{l}654.3 \\
517.2\end{array}$ & $\begin{array}{l}17.9 \\
12.3\end{array}$ & - & $\begin{array}{c}24.5 \\
3.1\end{array}$ \\
\hline & $\begin{array}{l}\text { Samsung SDI Co Ltd, Yongin, } \\
\text { Korea/ICR 18650-26D }\end{array}$ & & & 44.8 & & & $\begin{array}{l}4.2 \\
3.7\end{array}$ & $\begin{array}{l}116.5 \\
152.8 \\
\end{array}$ & $\begin{array}{l}683.2 \\
454.8 \\
\end{array}$ & $\begin{array}{l}18.6 \\
10.2 \\
\end{array}$ & - & $\begin{array}{c}18.1 \\
4.0\end{array}$ \\
\hline & $\begin{array}{l}\text { LG Chem Ltd, Seoul, } \\
\text { Korea/LGDB218650 }\end{array}$ & & & 46.5 & & & $\begin{array}{l}4.2 \\
3.7\end{array}$ & $\begin{array}{l}142.5 \\
168.0\end{array}$ & $\begin{array}{l}691.9 \\
407.1\end{array}$ & $\begin{array}{c}18.4 \\
8.0\end{array}$ & - & $\begin{array}{l}15.8 \\
3.3\end{array}$ \\
\hline Chen [6] & $\begin{array}{l}\text { Sony Energy Device, s. Jhu [5]/SE } \\
\text { US18650GR }\end{array}$ & 2.6 & $\begin{array}{l}\text { Cylindrical } \\
18650\end{array}$ & 46.5 & LCO/graphite & VSP2 & $\begin{array}{c}0 \\
30 \\
50 \\
80 \\
100 \\
\end{array}$ & $\begin{array}{c}- \\
175 \\
174 \\
140 \\
122\end{array}$ & $\begin{array}{c}- \\
241 \\
441 \\
638 \\
660\end{array}$ & $\begin{array}{c}- \\
2.5 \\
10.2 \\
19.0 \\
20.6\end{array}$ & $\begin{array}{l}200 \\
175 \\
175 \\
175 \\
160\end{array}$ & $\begin{array}{l}- \\
2.9 \\
4.0 \\
5.9 \\
16\end{array}$ \\
\hline \multirow{2}{*}{$\mathrm{Lu}[7]$} & - & & Cylindrical & $\begin{array}{l}38.15 \\
32.84 \\
\end{array}$ & LFP/- & \multirow{2}{*}{ VSP2 } & $\begin{array}{l}3.3 \\
3.6 \\
\end{array}$ & $\begin{array}{c}200.5 \\
199.94\end{array}$ & $\begin{array}{l}217.75 \\
243.23 \\
\end{array}$ & $\begin{array}{l}0.47 \\
1.02 \\
\end{array}$ & & $\begin{array}{c}17.2 \\
17.89 \\
\end{array}$ \\
\hline & & & 18650 & $\begin{array}{l}44.8 \\
44.89\end{array}$ & $\mathrm{LCO} /-$ & & $\begin{array}{l}3.7 \\
4.2\end{array}$ & $\begin{array}{l}160.45 \\
130.54\end{array}$ & $\begin{array}{l}280.10 \\
370.03\end{array}$ & $\begin{array}{l}3.91 \\
7.85\end{array}$ & & $\begin{array}{c}34.34 \\
116.44 \\
\end{array}$ \\
\hline \multirow{2}{*}{$\begin{array}{l}\text { Fleisch- } \\
\text { hammer } \\
{[8]}\end{array}$} & & \multirow[b]{2}{*}{1.5} & \multirow{2}{*}{$\begin{array}{l}\text { Cylindrical } \\
18650\end{array}$} & & NCM/LMO & \multirow[b]{2}{*}{ ARC } & Un-aged & 97.9 & \multirow[b]{2}{*}{ - } & & & \multirow{2}{*}{ 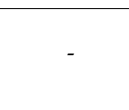 } \\
\hline & - & & & - & carbon/graphite & & $\begin{array}{l}\text { High-rate aged } \\
\text { Low temp. aged }\end{array}$ & $\begin{array}{l}80.5 \\
42.1\end{array}$ & & - & & \\
\hline
\end{tabular}


Table 1. Cont

\begin{tabular}{|c|c|c|c|c|c|c|c|c|c|c|c|c|}
\hline \multirow[b]{2}{*}{ Author } & \multicolumn{5}{|c|}{ Cell Type } & \multirow{2}{*}{$\begin{array}{l}\text { Calorimeter } \\
\text { Type }\end{array}$} & \multirow{2}{*}{$\begin{array}{l}\text { SOC in \% or } \\
\text { Voltage in V }\end{array}$} & \multirow{2}{*}{$\begin{array}{c}\text { Onset } \\
\text { Temperature of } \\
\text { Self-Heating in }{ }^{\circ} \mathrm{C}\end{array}$} & \multirow{2}{*}{$\begin{array}{c}\text { Maximum } \\
\text { Temperature } \\
T_{\max } \text { in }{ }^{\circ} \mathrm{C}\end{array}$} & \multirow{2}{*}{$\begin{array}{l}\text { Heat of } \\
\text { Reaction } \\
\Delta \mathrm{H} \text { in } \mathrm{kJ}\end{array}$} & \multirow[b]{2}{*}{$\begin{array}{c}T_{\text {Vent }} \text { in } \\
{ }^{\circ} \mathrm{C} \\
\quad\end{array}$} & \multirow{2}{*}{$\begin{array}{c}\text { Maximum } \\
\text { pressure } \\
P_{\max } \text { in Bar }\end{array}$} \\
\hline & Manufacturer/Name & $\begin{array}{l}\text { Capacity } \\
\text { in Ah }\end{array}$ & Dimensions & Weight in $\mathrm{g}$ & $\begin{array}{c}\text { Materials } \\
\text { (Cathode/Anode) }\end{array}$ & & & & & & & \\
\hline \multirow{11}{*}{$\begin{array}{c}\text { Mendoza- } \\
\text { Hernandez } \\
\text { [9] }\end{array}$} & & & & & & \multirow{11}{*}{ ARC } & 0 & 165.3 & & & & \\
\hline & & & & & & & 25 & 159.8 & & & & \\
\hline & - & 0.8 & Cylindrical & - & LCO/graphite & & $\begin{array}{l}50 \\
75\end{array}$ & 155.1 & - & - & - & - \\
\hline & & 0.8 & & -5 & LeV/grapinte & & 75 & 140.1 & 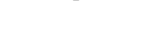 & -5 & - & 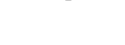 \\
\hline & & & & & & & 100 & 124.9 & & & & \\
\hline & & & & & & & 120 & 116.5 & & & & \\
\hline & \multirow{5}{*}{ - } & & & & & & 0 & - & & & & \\
\hline & & & & & & & 25 & 109.9 & & & & \\
\hline & & 0.72 & Cylindrical & - & LMO/graphite & & 50 & 104.9 & - & - & - & - \\
\hline & & & 18650 & & & & $\begin{array}{c}75 \\
100\end{array}$ & 104.9 & & & & \\
\hline & & & & & & & 120 & $\begin{array}{l}104.9 \\
99.8\end{array}$ & & & & \\
\hline \multirow{6}{*}{$\begin{array}{l}\text { Orendorff } \\
\text { [10] }\end{array}$} & & 2.6 & \multirow{6}{*}{ Cylindrical } & & LFP & \multirow{6}{*}{ ARC BTPV } & \multirow{6}{*}{ - } & 175 & & 19.4 & & 0.16 \\
\hline & & 3.4 & & & NCA & & & 160 & & 31.1 & & 0.45 \\
\hline & - & 20 & & - & LFP & & & 235 & - & 150 & - & 1.3 \\
\hline & & 27 & & & NCA & & & 110 & & 254 & & 4.1 \\
\hline & & 30 & & & LFP & & & 250 & & 272 & & 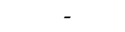 \\
\hline & & 38 & & & LFP & & & $233-246$ & & 289 & & 1.8 \\
\hline $\begin{array}{l}\text { Selman } \\
\text { [11] }\end{array}$ & $\begin{array}{l}\text { Sony Energy Device, } \\
\text { s. Jhu [5]/US18650 }\end{array}$ & & $\begin{array}{c}\text { Cylindrical } \\
18650\end{array}$ & - & $\begin{array}{l}\mathrm{LCO} / \\
\text { carbon }\end{array}$ & ARC & $\begin{array}{c}2.8 \\
4.06\end{array}$ & $\begin{array}{l}144 \\
104\end{array}$ & - & - & - & - \\
\hline \multirow{3}{*}{ This work } & & 1.65 & \multirow{3}{*}{$\begin{array}{l}\text { Cylindrical } \\
18650\end{array}$} & & & ARC & \multirow{3}{*}{100} & & & & \multirow{3}{*}{ - } & \\
\hline & - & 1.1 & & 39.7 & LFP & & & 90 & 259 & 7.3 & & \\
\hline & & 2.2 & & 41.7 & NMC & & & 91 & 731 & 24.9 & & \\
\hline
\end{tabular}




\section{Experimental}

For commercial 18650 lithium-ion cells with $\mathrm{LiMn}_{2} \mathrm{O}_{4}$ (LMO), $\mathrm{LiFePO}_{4}$ (LFP), and $\mathrm{Li}\left(\mathrm{Ni}_{0.33} \mathrm{Mn}_{0.33} \mathrm{Co}_{0.33}\right) \mathrm{O}_{2}$ (NMC) cathodes, four different thermal runaway testing methods have been applied in an accelerating rate calorimeter (es-ARC, Thermal Hazard Technology (THT), Bletchley, UK). The calorimeter chamber with a diameter of $10 \mathrm{~cm}$ and a height of $10 \mathrm{~cm}$ has one heater and one thermocouple located in the lid and in the bottom; and two heaters and thermocouples (all type N) in the side wall. In order to ensure comparable starting conditions, all tested cells were cycled three times with the constant current constant voltage (CCCV) method, which means charging at a constant current with a rate of $1 \mathrm{C}$, followed by charging with the maximal voltage until the current decreases to $\mathrm{C} / 10$. Afterwards, the cells were discharged with a $1 \mathrm{C}$ rate until the minimal voltage was reached (see Table 2). Finally, before the ARC test, the cells were charged to SOC 100. Following this, the tested cell was fixed on the lid of the calorimeter, as shown in Figure 1. The calorimeter temperature is controlled by a main or so-called bomb thermocouple attached to the surface of the cell. The heaters work until reaching the required temperatures regarding the measurement conditions and modes. An external steel casing serves as protection.

Table 2. Specifications of $18650 \mathrm{Li}$-ion cells with different cathode materials.

\begin{tabular}{cccc}
\hline Cathode Material & $\mathbf{L i M n}_{\mathbf{2}} \mathbf{O}_{\mathbf{4}}$ & $\mathbf{L i F e P O}$ & $\mathbf{L i}\left(\mathbf{N i}_{\mathbf{0 . 3 3}} \mathbf{M n}_{\mathbf{0 . 3 3}} \mathbf{C o}_{\mathbf{0 . 3 3}}\right) \mathbf{O}_{\mathbf{2}}$ \\
\hline $\mathrm{U}_{\min }-\mathrm{U}_{\text {max }}$ in V & $2.5-4.2$ & $2.0-3.6$ & $2.75-4.2$ \\
Nominal capacity in mAh & 1650 & 1100 & 2200 \\
Cycle life & 1000 & $>1000$ & $>300$ \\
Weight in g & 43.4 & 39.7 & 41.7 \\
Operating temperature in ${ }^{\circ} \mathrm{C}$ & $-20-60$ & $-30-60$ & $-20-60$ \\
\hline
\end{tabular}

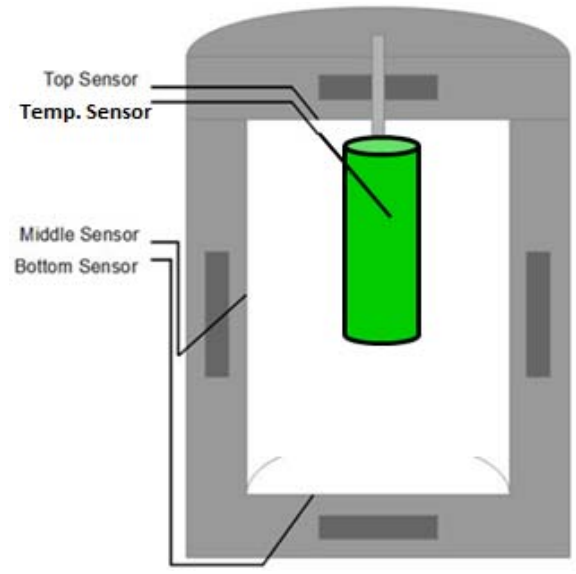

(a)

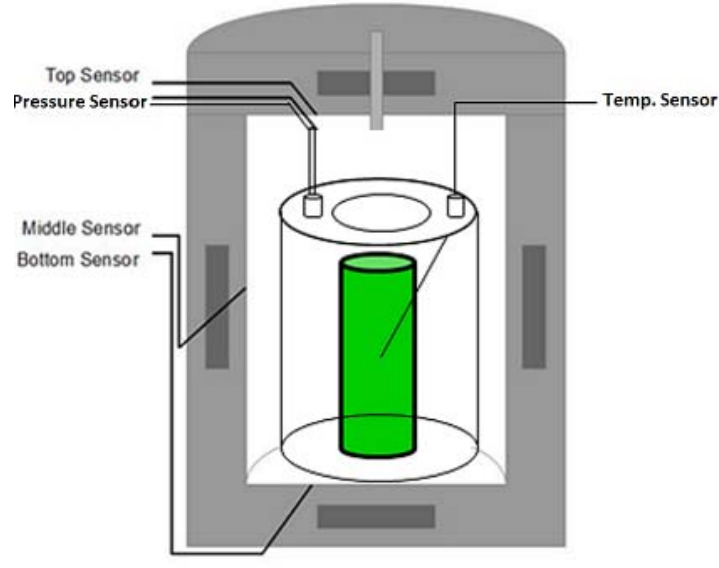

(b)

Figure 1. Setup of the cell in the ARC: (a) normal and internal pressure measurement; and (b) external pressure measurement.

\subsection{First Method (Only Temperature Measurement OT)}

In the first method, only the temperature and temperature rate were recorded (Figure 1a). The standard heat-wait-seek (HWS) method was applied for all measurements. This method allows an investigation of the thermal abuse of stored cells by excessive external heating, while they are neither charged nor discharged. The procedure and the recorded data are shown in Figures 2 and 3, respectively. The HWS method starts at $25^{\circ} \mathrm{C}$ in the heat mode, by heating up the cell in small temperature steps of $5^{\circ} \mathrm{C}$ (see Figure 3). At the end of each temperature step, the wait mode is activated for $15 \mathrm{~min}$, to reach thermal equilibrium. After reaching thermal equilibrium, the system enters Seek Mode, which monitors the temperature rate and presents two possible modes-exotherm 
mode or heat mode. The decision is related to the selected Temperature Rate Sensitivity. If the measured temperature rate is larger than this value, the system goes into Exotherm Mode. This mode provides an adiabatic environment, which means that no heat exchange between the sample and the surrounding space exists, so that the heat energy of the reactions can be monitored by the measured temperature. On the other hand, if the temperature rate is smaller than the value, the system goes back into Heat Mode. If the temperature exceeds the given final temperature $\mathrm{T}_{\mathrm{f}}\left(250^{\circ} \mathrm{C}\right)$, the heaters completely shut down and cool down the system by introducing pressurized air into the calorimeter chamber.

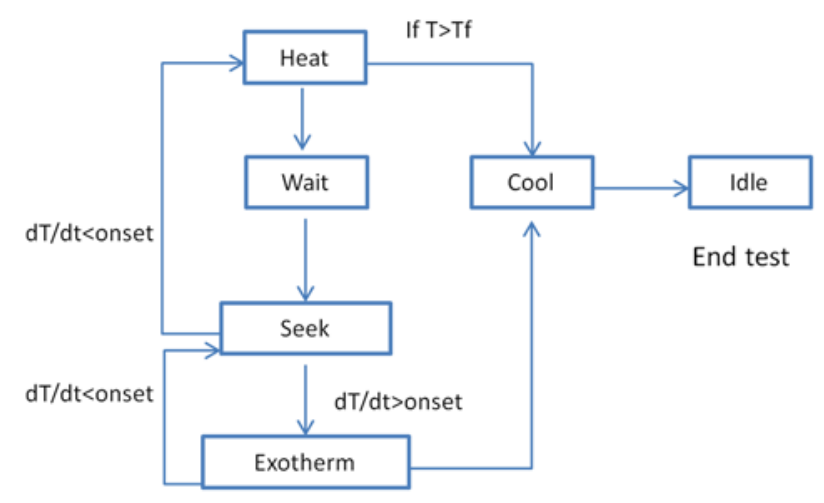

Figure 2. Process of the heat-wait-seek (HWS) method.

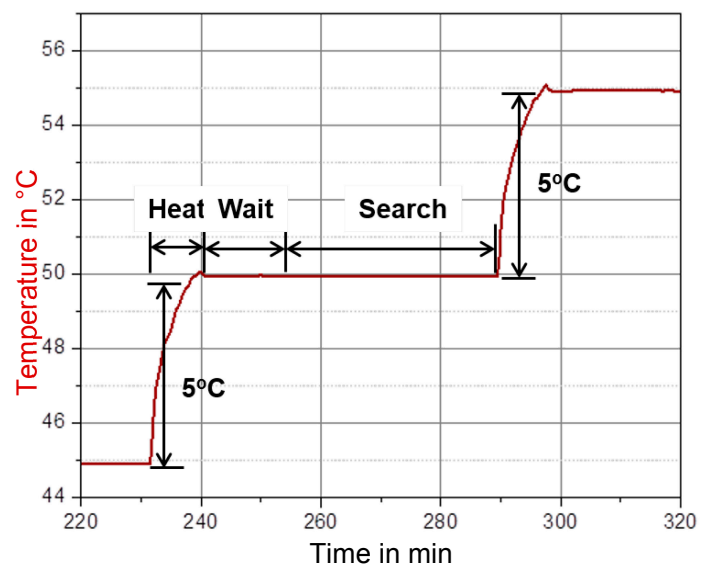

Figure 3. Example of cell surface temperature curve during HWS experiment in an ARC.

\subsection{Second Method(External Pressure Measurement EP)}

For the second method, an additional cylinder chamber was used in external pressure measurements (see Figure 1b). The thermocouple was introduced through a well-sealed hole and a pressure line connected with a pressure sensor was screwed onto the cylinder chamber. It was critical to screw every part of the cylinder chamber extremely tightly, to prevent leaks. Similar to the adiabatic environment, the system is only capable of monitoring the external pressure change if it is under an air-tight condition.

\subsection{Third Method (Internal Pressure Measurement IP)}

In contrast to the set-up of the second method, where the capillary leading to the pressure sensor was connected to the cylinder, in the third method, the capillary was directly introduced into the functional cell for internal pressure measurements (Figure 4). Therefore, a suitable point, which allows the capillary to pass through without disturbing the functionality of the cell, had to be found with the help of X-ray tomography images. 
X-ray tomography was conducted in the X-ray Imaging Laboratory at the Karlsruhe Institute of Technology (KIT), Institute for Applied Materials-Applied Materials Physics (IAM-AWP). X-ray micro-tomography scans were performed on the cell using a Phoenix v/tome/x s system (Phoenix X-ray GE Sensing \& Inspection Technologies $\mathrm{GmbH}$, Wunstorf, Germany). The battery was rotated $360^{\circ}$ around its long axis, whilst 1600 projections were captured with the microfocus tube operating at $200 \mathrm{kV}$ and $370(230) \mu \mathrm{A}$. The sample and detector were positioned in projection magnification, providing an effective voxel size of $75(48) \mu \mathrm{m}$ for the high resolution imaging. Tomography scans of the full cell were obtained, and a subsequent 3D analysis of the reconstructed image data was performed using VG studio max software 3.0, Volume Graphics Company, Heidelberg, Germany. For instance, Figure 4 shows a 3D rendering of the tomographic dataset for the 18650 cell with an LMO cathode. The spiral layer structure of the cell and the hollow central section are clearly revealed, as well as the safety valve on the top. It was easy to draw the conclusion that the best position for the pressure line is at the bottom center. The reasons for this are:

(1) The hollow is big enough for inserting a 1/16-inch diameter capillary.

(2) Inside the battery, the hollow section is located exactly in the center; nothing will be damaged when drilling a hole through the anode tab welding.

Then, the cells were resealed with epoxy resin. The described preparation procedure was conducted in an Argon-filled glovebox, because the cell components are very sensitive to moisture and oxygen.

Furthermore, the cells were cycled three times, and discharged completely to introduce the capillary. After resealing, the cells were cycled three times, and finally charged to SOC 100 . This shows that, even if the anode tab was damaged by the drilling, the cell was still functional after this procedure.

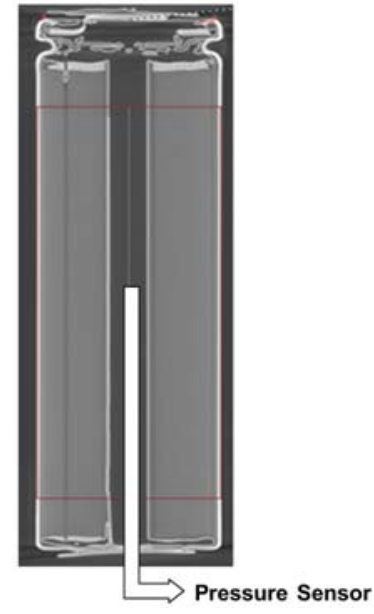

Figure 4. Setup for internal pressure measurement.

\subsection{Fourth Method (Ramp Heating Method (Hotbox Test))}

For the "ramp heating" method, the cells have been set up in the same way as described before for the HWS tests. However, instead of a stepwise heating of the cells, they were heated up continuously from $30^{\circ} \mathrm{C}$ to $250{ }^{\circ} \mathrm{C}$ in the ARC, at a constant rate of $5{ }^{\circ} \mathrm{C} / \mathrm{min}$. This mimics a hot box test. For this purpose, the measurements were operated in "ramp mode", with a high sensitivity value of $6{ }^{\circ} \mathrm{C} / \mathrm{min}$ to prevent automatic switching into the "exotherm mode". The system was used under adiabatic conditions, as in the other tests.

\subsection{Cells Preparation}

Before the thermal runaway tests, the capacity of the cells was determined by three full cycles, and finally, they were fully charged to state of charge $100 \%$ (SOC 100), because this is the most critical 
condition for thermal runaway according to [7]. The method of charge was $\mathrm{CC} / \mathrm{CV}$. This means that the cell is initially charged at a constant current at a $1 \mathrm{C}$ rate (CC) until the maximal voltage, and is then charged at a constant voltage (CV) with a decreasing current, until the current reaches $10 \%$ of its starting value.

\section{Results and Discussion}

\subsection{Results for 18650 Cells with $\mathrm{LiMn}_{2} \mathrm{O}_{4}$ Cathode by Using Different Methods}

In the following, the first three test methods are exemplarily demonstrated for the cell with the LMO cathode in the temperature range of $25^{\circ} \mathrm{C}$ to $250{ }^{\circ} \mathrm{C}$. Figure 5 compares the time evolution of the measured surface temperatures for the three different methods with three identical cells at SOC 100. From this figure, it is easy to distinguish the heat-wait-seek periods from the exotherm periods. At temperatures below about $80^{\circ} \mathrm{C}$, the temperature curve increased with steps of $5{ }^{\circ} \mathrm{C}$. Then, a first exothermic reaction can be observed at $91^{\circ} \mathrm{C}$, where the self-heating rate is higher than $0.02{ }^{\circ} \mathrm{C} / \mathrm{min}$. Following this, the system switched back to heat mode at $100{ }^{\circ} \mathrm{C}$, and the HWS mode was active until $110^{\circ} \mathrm{C}$. Finally, the temperature continuously increased in exotherm mode, until thermal runaway occurred.

Therefore, three stages were observed in the thermal runaway tests, which, according to the literature [1-3], were assigned according to:

(1) At about $90^{\circ} \mathrm{C}$, the SEI decomposed.

(2) At about $110^{\circ} \mathrm{C}$, an exothermic reaction between the embedded Lithium ions and electrolyte started, which resulted in the reduction of the electrolyte at the negative electrode.

(3) At about $200{ }^{\circ} \mathrm{C}$, an exothermic reaction between the active material and electrolyte at the positive electrode took place.

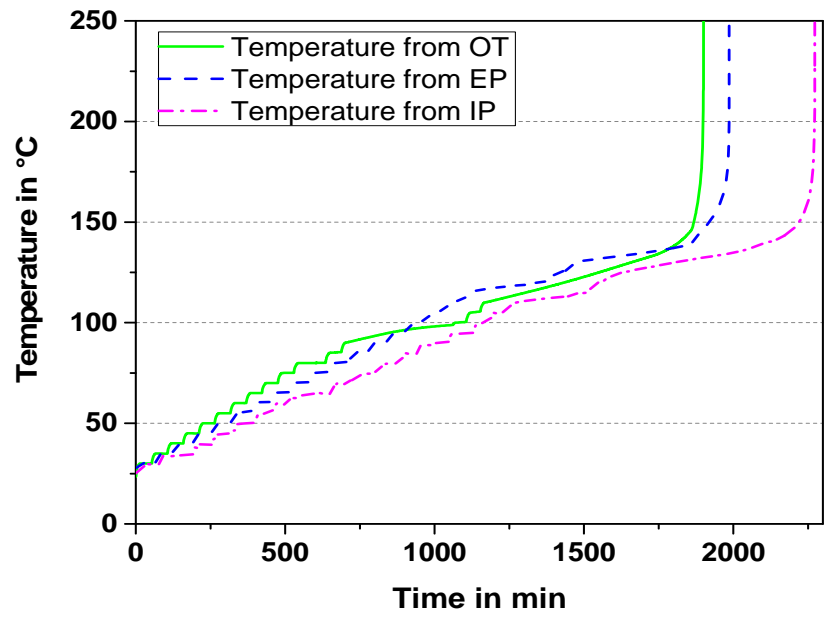

Figure 5. Comparison of temperature versus time curves measured with different methods.

When comparing the three curves, the time period in the HWS mode before switching into exotherm mode, increased from the only temperature via the external up to the internal pressure measurements. The reason for this is that, for the external pressure tests, the system needs to heat up the cylinder, and that for the internal pressure tests, some heat loss occurs via the metallic pressure line. Even though the three curves do not perfectly overlap, the tendencies are the same. Figure 6, which shows the temperature rate vs. the temperature, gives us a more specific view. From this figure, the three stages can be distinguished more easily. In the temperature region from $90{ }^{\circ} \mathrm{C}$ to $130{ }^{\circ} \mathrm{C}$, the temperature rate is lower than $0.1^{\circ} \mathrm{C} / \mathrm{min}$. From $130^{\circ} \mathrm{C}$ to $200^{\circ} \mathrm{C}$, the energy was released with a medium rate which was lower than $25^{\circ} \mathrm{C} / \mathrm{min}$. Above $225^{\circ} \mathrm{C}$, the exothermic reactions were violent, 
with a temperature rate over $100{ }^{\circ} \mathrm{C} / \mathrm{min}$, and could reach over $1000^{\circ} \mathrm{C} / \mathrm{min}$. These results indicated the degree and the destructive development of the exothermal reactions.

In Figure 7, the HWS method without pressure measurements (see Figure 7a) is compared to the ramp heating method (Figure $7 \mathrm{~b}$ ). From the latter, less information could be extracted: it can be seen that the temperature increased linearly at the beginning, as shown in Figure $7 \mathrm{~b}$, and that the inflection point is visible at about $150{ }^{\circ} \mathrm{C}$, which could also be observed in the curve of temperature rate vs. temperature (see Figure 6). Comparatively, the HWS Mode is relatively sensitive and revels the entire process of the thermal runaway.

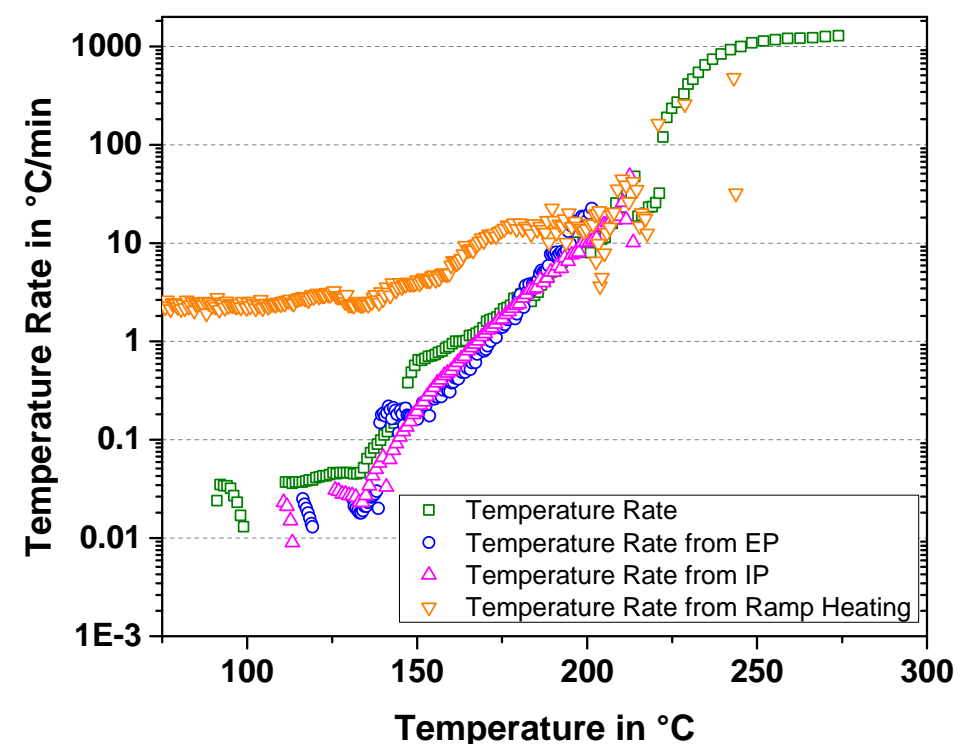

Figure 6. Comparison of temperature rate versus temperature curves measured with different methods.

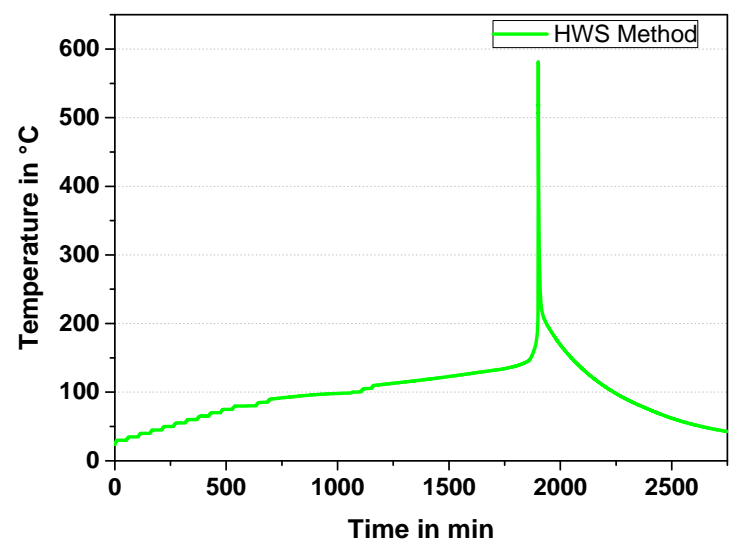

(a)

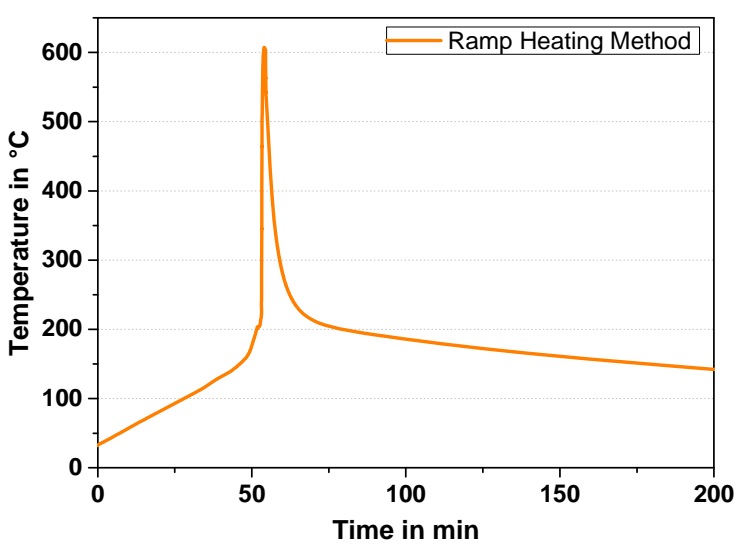

(b)

Figure 7. Comparison of temperature versus time curves: (a) HWS Method; and (b) ramp heating method.

In Figure 8, the pressure vs. time curves for the external and internal pressure tests are compared. In the external pressure curve (blue line) at about $130^{\circ} \mathrm{C}$, a small pressure rise can be observed, which marks the beginning of air leaking out of the cell. At the end of stage 2, it could be deduced that the battery had opened and gases were released. The external pressure increased continuously and dramatically until 21 bar at stage 3, matching the temperature change very well. From the internal pressure curve (magenta line), we can see that the internal pressure was increasing steadily during stage 1 and 2. In the transition from stage 2 to 3 , the cell vented and gases were released, which was 
indicated by a rapid internal pressure drop. The external pressure measurements and internal pressure measurements were different measurements that were operated separately, they do not represent parallel measurements on the same cell. Therefore, the time when the venting starts is different.

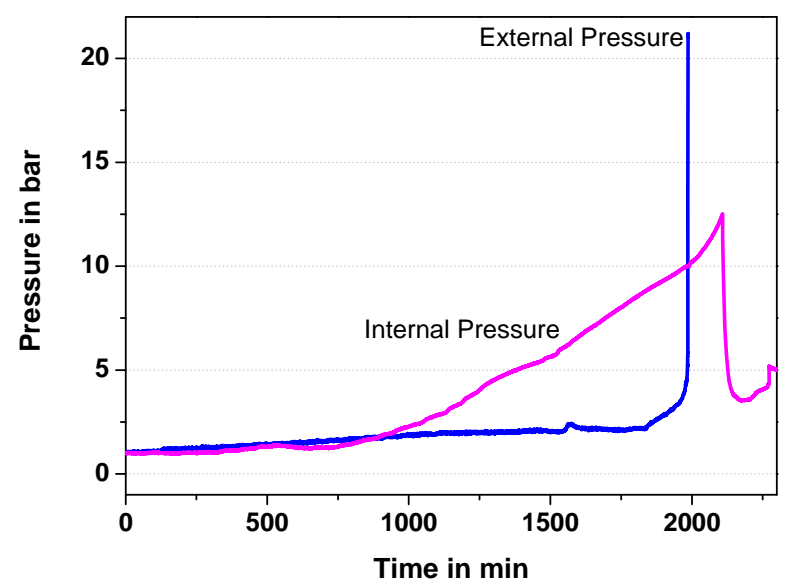

Figure 8. Comparison of pressure curves vs. time with different methods.

Finally, in order to correlate the temperature and pressure measurements, the pressure values measured from the external and the internal pressure tests are plotted vs. the temperature, as can be seen in Figure 9. For both the external and internal pressure curves, the inflexion occurred $130^{\circ} \mathrm{C}$, where the cells vented produced gases to reduce the internal pressure. At the same time, it caused an increase of the external pressure. The additional red line represents the expansion of the air in the additional cylinder chamber with increasing temperature according to the ideal gas law. As long as the cell is not venting, the ideal gas law should be a good approximation. For the external pressure measurement, the difference between the measured blue line and the red line can be regarded as the amount of gas that is released from the leaking cell. As the temperature increased, the difference became larger, indicating that more gases were produced. There was a gas leak from $130{ }^{\circ} \mathrm{C}$ and produced gases were released into the cylinder, due to exceeding the threshold pressure of the safety valve. At $200^{\circ} \mathrm{C}$, which was also the start temperature of stage 3 , the difference was significant. For the internal pressure measurement, starting at $80^{\circ} \mathrm{C}$, the difference continuously increased, indicating the beginning of gas production and SEI layer decomposition. After cooling, which is not shown here, the pressure fell below 10 bar again, which is the upper limit for the validity of the ideal gas law. Thus, according to Golubkov et al. [12], the ideal gas law equation can be used in order to calculate the amount of gas produced:

$$
\begin{aligned}
& n_{0}=\left(p_{0} \cdot V_{0}\right) /\left(R \cdot T_{0}\right) \\
& n_{1}=\left(p_{1} \cdot V_{0}\right) /\left(R \cdot T_{1}\right)
\end{aligned}
$$

where $n_{0}$ is the original air amount in the cylinder, $p_{0}$ is the pressure of the original air, $T_{0}$ represents the temperature of the original air, $V_{0}$ represents the volume of the cylinder, and $R$ is the gas constant, taken as $8.316 \mathrm{~J} \cdot \mathrm{K}^{-1} \cdot \mathrm{mol}^{-1}$. Similarly, $n_{1}$ represents the actual amount of gas measured during the measurements, $p_{1}$ is the pressure of the actual gases, and $T_{1}$ represents the temperature of the actual gases. From the parameters, depth: $72 \mathrm{~mm}$, outer diameter: $82 \mathrm{~mm}$, and thickness: $5 \mathrm{~mm}$, the volume is calculated: $2.73 \times 10^{-4} \mathrm{~m}^{3}$. At the beginning of the measurement, the temperature and pressure in the cylinder were $27.83^{\circ} \mathrm{C}(300.98 \mathrm{~K})$ and $1.11 \mathrm{bar}\left(1.11 \times 10^{5} \mathrm{~Pa}\right)$, which gives $n_{0}=12.05 \mathrm{mmol}$. At the end of the measurement, the thermocouple and pressure sensor detected that the sample temperature was $35.0^{\circ} \mathrm{C}(308.15 \mathrm{~K})$ and the pressure in the cylinder was 8.31 bar $\left(8.31 \times 10^{5} \mathrm{~Pa}\right)$, producing $n_{1}=88.53 \mathrm{mmol}$. Thus, the amount of gas produced during thermal runaway is (88.53-12.05) mmol, which is $76.48 \mathrm{mmol}$. 


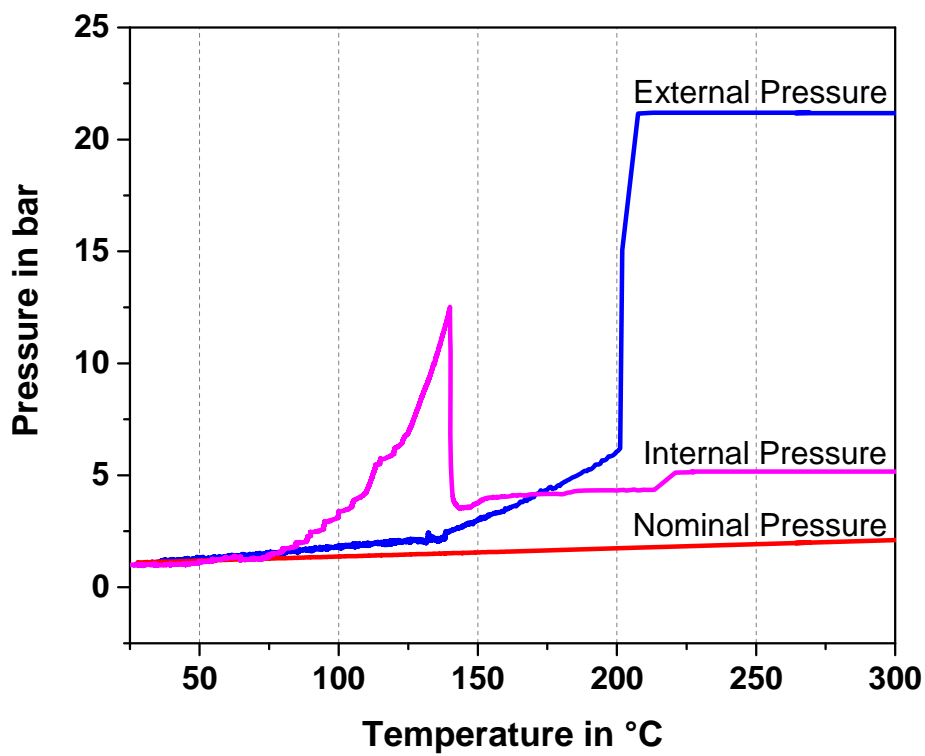

Figure 9. Comparison of pressure vs. temperature curves with different methods.

A similar procedure was described by Golubkov et al. [12] and the amount of gas produced was calculated from the measured external pressure. The cell with the LMO cathode released $76.5 \mathrm{mmol}$ gas during thermal runaway. Golubkov et al. reported that 18650 cells with LCO/NMC cathode material released $265 \mathrm{mmol}$ of gas, and those with pure NMC released $149 \mathrm{mmol}$. This comparison indicates a better exothermic stability of the LMO cathode.

\subsection{Results for 18650 Cells with Different Cathode Materials}

In the market, there are many kinds of batteries, varying from geometry to material. The most common structures of cathode materials are spinels, layered oxides, and olivines. Not only their electrical performance, but also their thermal properties, are quite different. Thus, every kind of these three active materials should be investigated and compared in "thermal runaway" studies [13]. The second part of this work focuses on a comparison of their thermal behavior in cylindrical 18650 cells. Their specifications are listed in Table 2. LMO, LFP, and NMC are chosen as examples for spinel, olivine, and layered structures, respectively, in this work.

Figure 10 shows the thermal behavior of 18650 cells during "thermal runaway" measurements. In all tests, the cells were heated between $30{ }^{\circ} \mathrm{C}$ and $250{ }^{\circ} \mathrm{C}$ with $5{ }^{\circ} \mathrm{C}$ increments in the search for self-heating at the sensitivity threshold of $0.01{ }^{\circ} \mathrm{C} / \mathrm{min}$. In the plot temperature vs. time, all of the onset temperatures of the exothermal reactions were similar, at about $90{ }^{\circ} \mathrm{C}$. A comparison of the maximum temperatures gives the highest value of $731^{\circ} \mathrm{C}$ for the NMC cathode, and a value of only $259{ }^{\circ} \mathrm{C}$ for the LFP cathode. One reason for this is the difference between the capacities, i.e., the nominal capacity of NMC (see Table 2) is twice that of LFP. Because the nominal capacity of LMO lies in between, its maximum temperature is $581{ }^{\circ} \mathrm{C}$. In terms of the length of heating time which was required to activate the exothermal reactions, NMC and LFP took significantly longer than LMO.

In the temperature rate vs. temperature plot shown in Figure 11, the three different stages of thermal runaway mentioned before can be observed and distinguished. The LFP cell never entered stage 3, with temperature rates staying below $3{ }^{\circ} \mathrm{C} / \mathrm{min}$. In contrast, the $\mathrm{LMO}$ cell reached a maximum rate of $1285{ }^{\circ} \mathrm{C} / \mathrm{min}$ and the $\mathrm{NMC}$ cell reached $7580{ }^{\circ} \mathrm{C} / \mathrm{min}$. In the temperature region between $80^{\circ} \mathrm{C}$ and $130{ }^{\circ} \mathrm{C}$, the SEI decomposed. The temperature rate of LFP was the lowest among these three materials, while NMC and LMO were in the same range. The much lower maximum temperature rate of LFP can not only be attributed to the lower capacity, but also to the much higher thermal stability of this nanoscale material. 


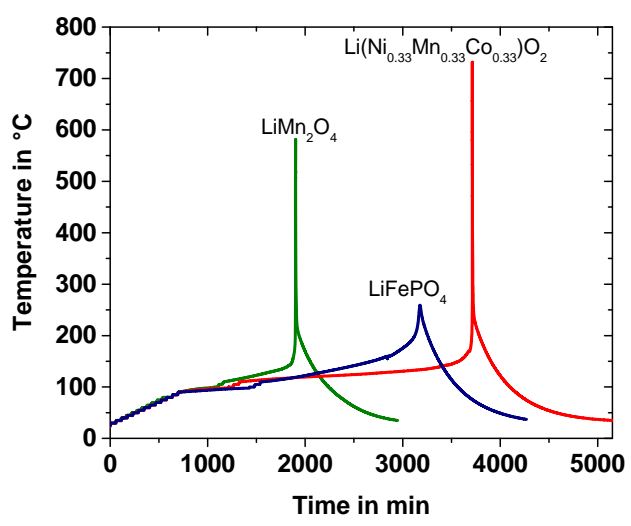

Figure 10. Temperature versus time curves for 18650 cells during HWS tests in an ARC with different cathode materials.

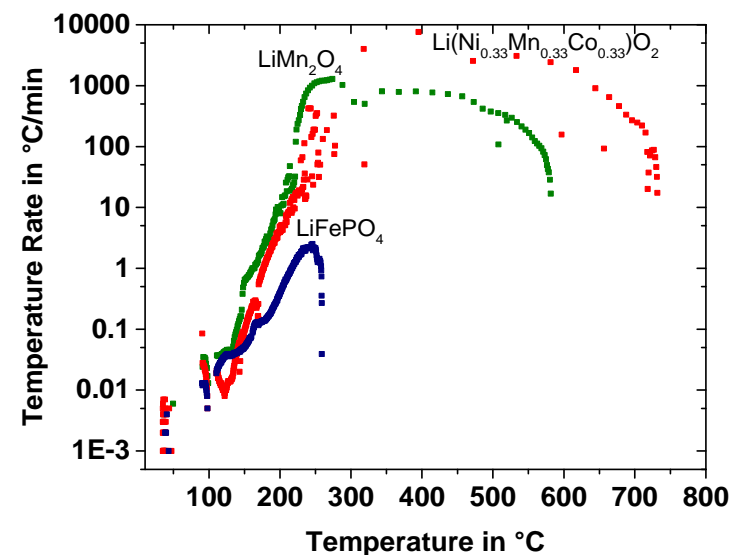

Figure 11. Temperature rate versus temperature curves for 18650 cells during HWS tests in an ARC with different cathode materials.

According to the simplified equation for calculating the thermokinetic parameters proposed by Jhu et al. [4,5], which is based on the Arrhenius law, the temperature rate or self-heating rate can be expressed as follows:

$$
\ln (\mathrm{d} T / \mathrm{d} t) \approx \ln \left(\Delta T_{\mathrm{ad}} \cdot A\right)-E_{\mathrm{a}} /\left(k_{\mathrm{B}} \cdot T\right)
$$

When the $\mathrm{ARC}$ is operating under adiabatic conditions in exotherm mode, there is no heat loss to the surroundings. Thus, we can consider that the temperature rise is only caused by the self-heating reactions in the cell and the mass specific heat of the reaction $(\mathrm{J} / \mathrm{g})$ for each stage can be calculated with the following equation:

$$
\Delta H / m_{\text {cell }}=c_{\mathrm{p}} \cdot \Delta T_{\mathrm{ad}}
$$

where $A$ is the pre-exponential factor $\left(\mathrm{min}^{-1}\right) ; \Delta T_{\mathrm{ad}}$ is the adiabatic temperature rise (K), i.e., the difference between the initial exothermic temperature $T_{0}$ and the maximum temperature $T_{\max }$; $E_{\mathrm{a}}$ is the activation energy $(\mathrm{eV}) ; k_{\mathrm{B}}$ is Boltzmann's constant $\left(8.62 \times 10^{-5} \mathrm{eV} \cdot \mathrm{K}^{-1}\right) ; m_{\text {cell }}$ is the cell mass $(\mathrm{g})$; and $c_{\mathrm{p}}$ is the heat capacity $(\mathrm{J} / \mathrm{g} \cdot \mathrm{K})$. Thus, by plotting the natural logarithm of the self-heating rate versus the inverse of temperature, as shown in Figure 12, the activation energy and frequency factor of the different cells can be calculated. The data obtained from this Arrhenius plot are listed in Table 3. Li-ion cells with an LFP cathode have the lowest $T_{\max }$ and $(\mathrm{d} T / \mathrm{d} t)_{\max }$, while cells with the NMC cathode show the highest $T_{\max }$ and $(\mathrm{d} T / \mathrm{dt})_{\max }$. For calculating the heat of the reaction using Equation (4), the heat capacity was measured as described in Schuster et al. [14]. The listed heat of the reaction is the sum of the heats of the reactions of the different stages. The heats of the reactions are in good agreement with the results from the literature [2,15] as are the activation energies [5]. 
The next step could be to use the derived thermokinetic parameters as input parameters for our coupled electrochemical thermal model [16]. This model is based on the porous electrode theory of Newman and Tiedemann [17] and has been extended with a simple combustion model emerging from reaction kinetics, including various types of heat sources based on an Arrhenius law.

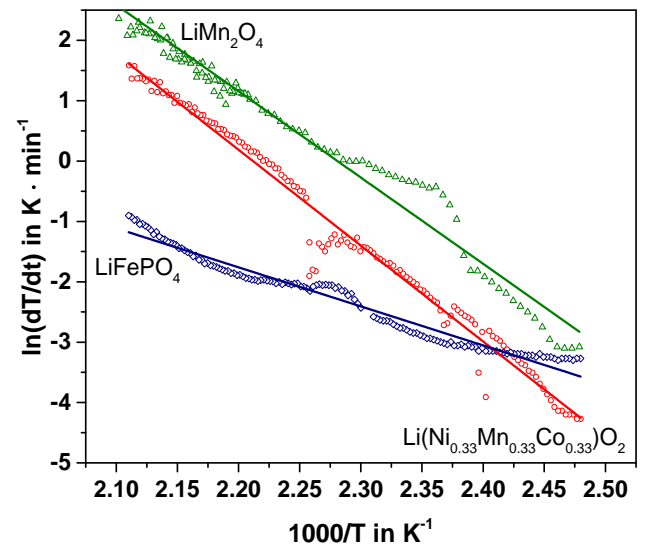

Figure 12. Natural logarithm of the self-heating rate versus inverse of temperature curves for 18650 cells with different cathode materials. The three lines are linear fits according to the Arrhenius law.

Table 3. Thermal runaway test results of $18650 \mathrm{Li}$-ion cells with different cathode materials.

\begin{tabular}{|c|c|c|c|}
\hline Cathode Material & $\mathrm{LiMn}_{2} \mathrm{O}_{4}$ & $\mathrm{LiFePO}_{4}$ & $\operatorname{Li}\left(\mathrm{Ni}_{0.33} \mathrm{Mn}_{0.33} \mathrm{Co}_{0.33}\right) \mathrm{O}_{2}$ \\
\hline Onset temperature of self-heating in ${ }^{\circ} \mathrm{C}$ & 91 & 90 & 91 \\
\hline$T_{\max }$ in ${ }^{\circ} \mathrm{C}$ & 581 & 259 & 731 \\
\hline$(\mathrm{d} T / \mathrm{d} t)_{\max }$ in ${ }^{\circ} \mathrm{C} / \mathrm{min}$ & 1285 & 3 & 7577 \\
\hline$c_{p}$ at $60^{\circ} \mathrm{C} \mathrm{SOC} 100 \mathrm{in} \mathrm{J} / \mathrm{g} \cdot \mathrm{K}$ & 0.83 & 1.19 & 0.95 \\
\hline$E_{\mathrm{a}}$ in $\mathrm{eV}$ & 1.24 & 0.56 & 1.37 \\
\hline Reaction heat in $\mathrm{J} / \mathrm{g}$ & 391 & 184 & 597 \\
\hline Reaction heat in J/g & $350-640[2,15]$ & $260[15]$ & $600[15]$ \\
\hline
\end{tabular}

\section{Conclusions}

Three stages have been observed in thermal runaway tests in $18650 \mathrm{Li}$-ion cells with an LMO cathode by correlating temperature and pressure curves. The first stage began with the production of gas at about $90{ }^{\circ} \mathrm{C}$. The reaction in the first stage was likely to be the SEI layer decomposition. The onset temperature of thermal runaway, which means the temperature at which the self-heating reaction starts, thus leading to thermal runaway, was about $110^{\circ} \mathrm{C}$. The amount of gas produced was $76.48 \mathrm{mmol}$ in thermal runaway. In future studies, it could be interesting to confirm these stages and analyze the gas produced and the material components after thermal runaway, using post-mortem analysis by opening the cells that were frozen at the different stages. Furthermore, the effects of different SOCs and of ageing could be studied. In addition, the developed pressure tests could be applied to cycling in the ARC under adiabatic conditions, in order to study the effect of different charging and discharging rates.

For $18650 \mathrm{Li}$-ion cells with different cathode materials, the thermal runaway tests confirmed that cells with an LFP cathode exhibited a good stability under thermal abuse, while cells with an NMC cathode presented a poor temperature tolerance at high temperatures.

Acknowledgments: This R\&D project is part of the project "Integrated components und integrated design of energy efficient battery systems" (IKEBA) which was funded by the German Federal Ministry for Education and Research (BMBF) within the framework "IKT 2020 Research for Innovations" under the grant 16N12515 and was supervised by the Project Management Agency VDI I VDE I IT. The authors would like to express their gratitude to A. Maier, IAM-AWP, for recording the X-ray tomography images. 
Author Contributions: Hans Jürgen Seifert inspired and conducted the fundamental idea of this work; Carlos Ziebert and Magnus Rohde conceived and designed the experiments; Wenjiao Zhao, Boxia Lei, and Nils Uhlmann performed the experiments; Boxia Lei and Wenjiao Zhao analyzed the data.

Conflicts of Interest: The authors declare no conflict of interest. The funding agency had no role in the design of the study; in the collection, analysis, or interpretation of data; in the writing of the manuscript, and in the decision to publish the results.

\section{References}

1. Roth, E.P.; Doughty, D.H. Thermal abuse performance of high-power 18650 Li-ion cells. J. Power Sources 2004, 128, 308-318. [CrossRef]

2. Spotnitz, R.; Franklin, J. Abuse behavior of high-power, lithium-ion cells. J. Power Sources 2003, 113, 81-100. [CrossRef]

3. Abraham, D.P.; Roth, E.P.; Kostecki, R.; McCarthy, K.; MacLaren, S.; Doughty, D.H. Diagnostic examination of thermally abused high-power lithium-ion cells. J. Power Sources 2006, 161, 648-657. [CrossRef]

4. Jhu, C.Y.; Wang, Y.W.; Wen, C.Y.; Shu, C.M. Thermal runaway potential of $\mathrm{LiCoO}_{2}$ and $\mathrm{Li}\left(\mathrm{Ni}_{1 / 3} \mathrm{Co}_{1 / 3} \mathrm{Mn}_{1 / 3}\right) \mathrm{O}_{2}$ batteries determined with adiabatic calorimetry methodology. Appl. Energy 2012, 100, 127-131. [CrossRef]

5. Jhu, C.Y.; Wang, Y.W.; Shu, C.M.; Chang, J.C.; Wu, H.C. Thermal explosion hazards on 18650 lithium ion batteries with a VSP2 adiabatic calorimeter. J. Hazard. Mater. 2011, 192, 99-107. [CrossRef] [PubMed]

6. Chen, W.C.; Wang, Y.W.; Shu, C.M. Adiabatic calorimetry test of the reaction kinetics and self-heating model for $18650 \mathrm{Li}$-ion cells in various states of charge. J. Power Sources 2016, 318, 200-209. [CrossRef]

7. Lu, T.; Chiang, C.; Wu, S.; Chen, K.; Lin, S.; Wen, C.; Shu, C. Thermal hazard evaluations of 18650 lithium-ion batteries by an adiabatic calorimeter. J Therm. Anal. Calorim. 2013, 114, 1083-1088. [CrossRef]

8. Fleischhammer, M.; Waldmann, T.; Bisle, G.; Hogg, B.I. Wohlfahrt-Mehrens, M. Interaction of cyclic ageing at high-rate and low temperatures and safety in lithium-ion batteries. J. Power Sources 2015, 274, 432-439. [CrossRef]

9. Mendoza-Hernandez, O.; Ishikawa, H.; Nishikawa, Y.; Maruyama, Y.; Umeda, M. Cathode material comparison of thermal runaway behavior of Li-ion cells at different state of charges including over charge. J. Power Sources 2105, 280, 499-504. [CrossRef]

10. Orendorff, C.; Lamb, J.; Steele, L.A.; Spangler, S.W.; Langendorf, J. Quantification of Lithium-Ion Cell Thermal Runaway Energetics; SAND2016-0486; Sandia National Laboratories: Albuquerque, NM, USA, 2016.

11. Selman, J.R.; Hallaj, S.A.; Uchida, I.; Hirano, Y. Cooperative research on safety fundamentals of lithium batteries. J. Power Sources 2001, 726, 97-98. [CrossRef]

12. Golubkov, A.W.; Fuchs, D.; Wagner, J.; Wiltsche, H.; Stangl, C.; Fauler, G.; Voitic, G.; Thaler, A.; Hacker, V. Thermal-runaway experiments on consumer Li-ion batteries with metal-oxide and olivin-type cathodes. J. RSC Adv. 2014, 4, 3633-3642. [CrossRef]

13. Gulbinska, M.K. Lithium-ion Battery Materials and Engineering; Springer: London, UK, 2014; p. 3.

14. Schuster, E.; Ziebert, C.; Melcher, A.; Rohde, M.; Seifert, H.J. Thermal behavior and electrochemical heat generation in a commercial 40 Ah lithium ion pouch cell. J. Power Sources 2015, 286, 580-589. [CrossRef]

15. Xiang, H.F.; Wang, H.; Chen, C.H.; Ge, X.W.; Guo, S.; Sun, J.H.; Hu, W.Q. Thermal stability of LiPF6-based electrolyte and effect of contact with various delithiated cathodes of Li-ion batteries. J. Power Sources 2009, 191, 575-581. [CrossRef]

16. Melcher, A.; Ziebert, C.; Rohde, M.; Seifert, H.J. Modeling and simulation of the thermal runaway behavior of cylindrical Li-ion cells-Computing of critical parameters. Energies 2016, 9, 292. [CrossRef]

17. Newman, J.; Tiedemann, W. Temperature rise in a battery module with constant heat generation. J. Electrochem. Soc. 1995, 142, 1054-1057. [CrossRef] 